\title{
Sources and doses of organic substrates in the production of tamarind rootstock
}

Jose Maria Costa ${ }^{*}$, Eduardo Castro Pereira', Francisco Mickael de Medeiros Câmara², Vander Mendonça', Wagner César de Farias', Luciana Freitas de Medeiros Mendonça'

\begin{abstract}
In order to evaluate the performance of different organic sources, the composition of the substrate to produce rootstocks of tamarind and nutritional status, an experiment was carried out in the seedling nursery at the Universidade Federal Rural do Semi-Árido Mossoró, RN. The experimental design was a randomized complete block, in a $3 \times 4$ factorial design with four replications. The first factor consisted of three organic sources (bovine manure, goat manure and commercial organic compound) and the second factor of four ratios of these sources $\left(0,20,40\right.$ and $\left.60 \% \vee v^{-1}\right)$ mixed with soil. As a control was used only soil were 12 treatments with 10 plants per plot, totaling 480 plants. Morphological and nutritional characteristics were evaluated. The goat manure source provided the best results for the evaluated morphological characteristics. The proportion of $40 \%$ of organic matter, regardless of the organic source added to the substrate, favored the better development of tamarind seedlings.
\end{abstract}

Keywords: Tamarindus indica L; nutrition; quality rootstock

\section{Introduction}

The tamarind is a species cultivated in places of warm climate, showing itself well adapted in several Brazilian regions. Diffused and cultivated for centuries in Brazil, is a tree that, due to the beauty and production of shade, is much appreciated for ornamentation and afforestation. In addition to medicinal properties, fruits are widely used in the production of juice. jellies, sweets and ice creams (Ferreira et al., 2008).

In the Brazilian Northeast, the cultivation of the tamarind tree is carried out by small farmers. The harvest coincides with the dry season in the corn and bean off crop, which allows extra income to the farmers, helping to set the man in the field.

The production of quality healthy and well developed seedlings is a factor of extreme importance for any crop, especially for those that have perennial character, as is the case of tamarind. When this stage is well conducted, it has a more sustainable activity, with greater productivity and lower cost, being one of the main factors of success in the formation of an orchard (Góes et al., 2011).

Adequate formulation of the substrate is a fundamental requirement for success in the production of rootstocks. The ideal substratum should have ease of acquisition and transport, 
nutrient availability and adequate $\mathrm{pH}$ (Almeida et al., 2012; Kusdra et al., 2008). In addition to good texture and structure, it must have good cation exchange capacity and low salinity (Dias et al., 2007; Silva et al., 2012).

Organic matter is a very important component of the substrate. It brings several benefits in the improvement of the physical, chemical and biological attributes, such as: increase in porosity, aeration, volume of water available and space for roots to grow, nutrient supply, increase of the cation exchange capacity, $\mathrm{pH}$ and in the saturation by bases (Silva et al., 2012; Morais et al., 2012).

The tamarind tree is a fruit tree cultivated by small farmers and it is in process of area expansion in Brazil, but without information on the different types of management, for example, in the production of rootstock using alternative materials with low cost and easy to acquire.

In view of the foregoing, the objective of this work was to evaluate the effect of three organic sources in different proportions on the substrate composition and nutritional status of the tamarind rootstock.

\section{Material and methods}

The experiment was carried out from March to December 2013 at the seedling nursery of the Universidade Federal do Semi-Árido (UFERSA), Mossoró, RN.

Seeds from healthy and mature fruits obtained from a single tamarind tree plant in the UFERSA orchard were used in the experiments. Initially, the peel was removed from the selected fruits which were subsequently immersed in a container with water for a period of 12 hours to facilitate the separation of the seeds from the pulp. The seeds were washed on a fine mesh sieve under running water. Separated from pulp and bark residues, these were selected manually, where small and damaged seeds were eliminated. After this step the seeds were placed on a newspaper to dry in an aired and shaded place for a day.

The rootstocks were produced in black polyethylene bags with dimensions of $19 \times 25 \mathrm{~cm}$, with capacity of $(3.2 \mathrm{~L})$ and perforated in the lower part to allow the drainage of water. Daily irrigations were performed in the morning and at the end of the afternoon using a micro-sprinkler system with a mean flow rate of $40 \mathrm{~L} \mathrm{~h}^{-1}$, with emitters installed 2 meters high in relation to the soil surface.

The used substrates resulted from the mixing of three organic sources (Bovine Manure (BM), Goat Manure (GM) and a commercial Organic Compound (ecoferti $\left.\left.{ }^{\circledR}\right),(\mathrm{CO})\right]$ which were added to the soil in proportions of 0,20 , 40 and $60 \% \vee v^{-1}$. A single superphosphate dose of $0.16 \mathrm{~kg} \mathrm{~m}^{-3}$ was added in the plot, using a precision analytical balance. To measure the volume of the organic sources, a graduated container with a capacity of 10 liters was used.

The experimental design used was in randomized complete blocks, in a 3x4 factorial scheme, with four replications. The first factor was constituted by the three organic sources and the second factor by the four proportions of these sources in mixture with soil (Table 1). As a control, soil was used as substrate, and each plot was formed by ten plants, totaling 480 plants.

At 140 days after sowing (DAS), five plants were randomly evaluated by treatment, performing destructive and non-destructive analyzes to determine the morphological and nutritional characteristics. The evaluated characteristics were: aerial part length (APL), lap diameter (LD), number of leaves per plant (NL), shoot dry mass (SDM), root dry mass (RDM), root system length (RSL), total dry mass (TDM).

During the period of implantation of the experiment samples were collected from each substrate and sent to the UFERSA chemical analysis laboratory. The values of electrical conductivity (EC), $\mathrm{pH}, \mathrm{N}, \mathrm{K}, \mathrm{P}, \mathrm{Ca}, \mathrm{Mg}, \mathrm{Na}$ and organic matter (OM), on the substrate of each treatment, based on the methodology of (Embrapa, 2009), (Table 2).

After determination of the shoot dry matter samples were taken from leaves of all treatments, which were later ground in a Wiley mill equipped with a a 20 mesh sieve and stored in hermetically sealed vials. The levels of $N, P$, $K$ in the leaves were determined based on the Embrapa methodology (Embrapa, 2009).

The data were submitted to the analysis of variance by applying the Test $F$, the means 
compared by the Tukey test to $5 \%$ of probability and for the qualitative data the regression analysis was performed using the SISVAR program
(Ferreira, 2011). The adjustment of the regression curves was performed using the Table curve $2 d$ program (Jandel Scientific, 1991).

Table 1. Combinations of the three organic sources, for composition of the substrates and formation of the treatments used in the experiment. Mossoró, RN, 2014.

\begin{tabular}{ll}
\hline TREATMENTS & COMBINATIONS \\
\hline Treatment 1 & $100 \%$ de soil \\
Treatment 2 & $20 \%$ of bovine manure $+80 \%$ of soil \\
Treatment 3 & $40 \%$ of bovine manure $+60 \%$ of soil \\
Treatment 4 & $60 \%$ of bovine manure $+40 \%$ of soil \\
Treatment 5 & $100 \%$ of soil \\
Treatment 6 & $20 \%$ of goat manure $+80 \%$ of soil \\
Treatment 7 & $40 \%$ of goat manure $+60 \%$ of soil \\
Treatment 8 & $60 \%$ of goat manure $+40 \%$ of soil \\
Treatment 9 & $100 \%$ of soil \\
Treatment 10 & $20 \%$ of commercial organic compound $+80 \%$ of soil \\
Treatment 11 & $40 \%$ of commercial organic compound $+60 \%$ of soil \\
Treatment 12 & $60 \%$ of commercial organic compound $+40 \%$ of soil \\
\hline
\end{tabular}

Table 2. Chemical characterization of the treatments used in the production of tamarind rootstocks (Mossoró, RN, 2014).

\begin{tabular}{|c|c|c|c|c|c|c|c|c|}
\hline \multirow[b]{2}{*}{ Treatments } & $\mathrm{pH}$ & EC & OM & $\mathrm{N}$ & $P$ & $\mathrm{~K}^{+}$ & $\mathrm{Na}^{+}$ & \multirow{2}{*}{$\frac{\mathrm{Ca}^{2+}}{{\mathrm{cmolc} \mathrm{dm}^{-3}}^{-3}}$} \\
\hline & (water) & $\mathrm{dS} / \mathrm{m}$ & \multicolumn{2}{|c|}{----g kg-1----- } & \multicolumn{3}{|c|}{ - } & \\
\hline Treatment 1 & 7.00 & 0.10 & 3.83 & 0.13 & 3.86 & 793.70 & 47.99 & 1.20 \\
\hline Treatment 2 & 8.05 & 2.44 & 30.13 & 0.21 & 393.57 & 1818.18 & 312.09 & 6.30 \\
\hline Treatment 3 & 7.96 & 0.24 & 56.11 & 0.28 & 420.58 & 2207.68 & 766.38 & 6.80 \\
\hline Treatment 4 & 8.35 & 2.93 & 25.49 & 1.05 & 681.65 & 487.66 & 949.21 & 8.00 \\
\hline Treatment 5 & 7.00 & 0.10 & 3.83 & 0.63 & 3.86 & 498.21 & 47.99 & 1.20 \\
\hline Treatment 6 & 7.10 & 0.70 & 19.38 & 0.63 & 582.62 & 714.60 & 624.17 & 4.40 \\
\hline Treatment 7 & 7.30 & 1.41 & 31.57 & 0.42 & 192.94 & 1082.46 & 116.30 & 5.30 \\
\hline Treatment 8 & 7.20 & 2.05 & 20.43 & 0.84 & 151.79 & 487.66 & 197.56 & 8.00 \\
\hline Treatment 9 & 7.00 & 0.10 & 3.83 & 0.63 & 3.86 & 1039.18 & 47.99 & 1.20 \\
\hline Treatment 10 & 7.71 & 1.34 & 31.89 & 0.56 & 127.35 & 1709.99 & 177.25 & 4.30 \\
\hline Treatment 11 & 7.66 & 1.53 & 21.39 & 0.35 & 113.20 & 3506.02 & 319.45 & 7.50 \\
\hline Treatment 12 & 7.64 & 3.90 & 30.95 & 0.42 & 93.91 & 3506.02 & 705.43 & 8.50 \\
\hline
\end{tabular}

\section{Results and discussion}

No significant effect of the interaction between sources and proportions of the organic materials in the substrate was observed for all evaluated characteristics: lap diameter, number of leaves, root dry mass, root system growth, total dry mass, except for the characteristics length and dry mass of the aerial part of the tamarind rootstocks, indicating that for most of the characteristics the factors acted independently.

It was verified for the APL that the best treatment was with goat manure in the proportion of $40.30 \% \mathrm{v} \mathrm{v}^{-1}$ resulting in maximum height $73.15 \mathrm{~cm}$, while the organic compound in the proportion of $45.74 \% \vee v^{-1}$ promoted a growth of $66.49 \mathrm{~cm}$ in height. Bovine manure showed the lowest growth, and it was observed that in the proportion of $37.81 \% \mathrm{v}^{-1}$ it obtained an increase of $60.07 \mathrm{~cm}$, not statistically differing from the organic compound (Figure 1).

This behavior may be related to the substrate nutritional characteristics formulated with goat manure in the proportion of $40 \%$ with values $(7.30,0.42)$ of $\mathrm{pH}$ and $\mathrm{N}$ respectively (Table 2). The $\mathrm{pH}$ is close to the recommended range for the crop which is 5.5 to 6.5 in this condition probably had a better availability of nitrogen that is directly related to the growth of the plants, thus allowing the rootstocks to reach the point of grafting faster in relation to the other treatments, promoting gain of time and lower cost of handling.

The results obtained in this study corroborated with those observed by Mendonça 
et al. (2014) and Mesquita et al. (2012), which studying different substrates in the production of tamarind rootstocks and papaya seedlings, respectively, observed that there was better APL when goat manure, sheep manure and bovine manure were used.

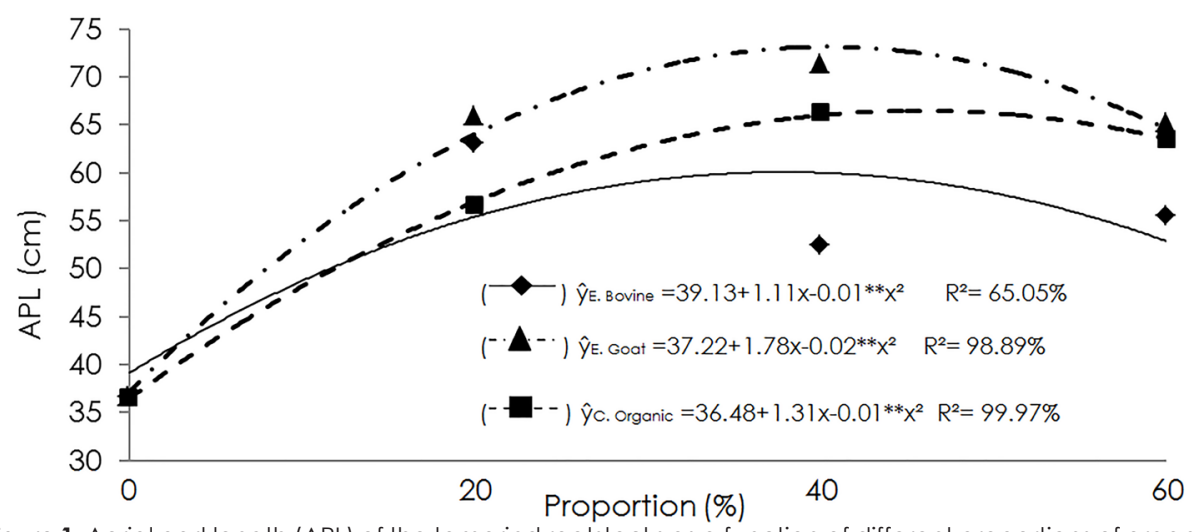

Figure 1. Aerial part length (APL) of the tamarind rootstocks as a function of different proportions of organic matter incorporated in the substrates. Mossoró, RN, 2014.

The interaction between organic sources and proportions for SDM shown in Figure 2, with the best treatment containing goat manure in the proportion of $43.44 \% \vee v^{-1}$ promoting a maximum SDM of $45.28 \mathrm{~g}$, the organic compound in the proportion of $46.11 \% \mathrm{v} \mathrm{v}^{-1}$ resulted in an increase of $36.60 \mathrm{~g}$. While the bovine manure obtained the lowest result, it was found that in the proportion of $40 \% \vee v^{-1}$ obtained maximum of $35.59 \mathrm{~g}$. Similar behavior was observed by Pereira et al. (2016) when evaluating different organic sources and phosphorus doses in tamarind rootsrocks production, verified that goat manure and organic compost provided seedlings with better SDM values.

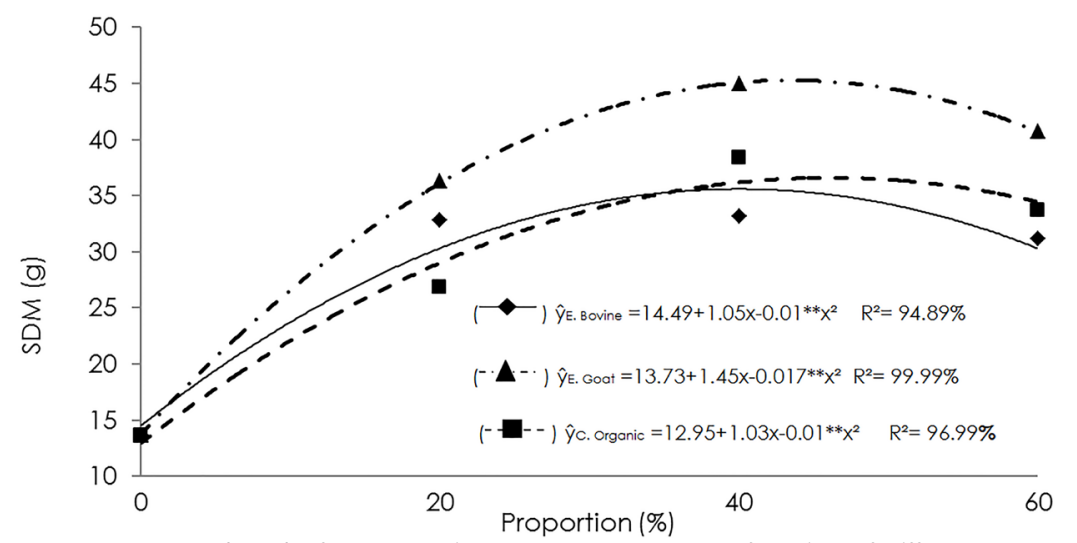

Figure 2. Shoot dry mass (SDM) of the tamarind tree rootstocks as a function of different proportions of organic matter incorporated in the substrates. Mossoró, RN, 2014.

The behavior observed in Figure 2 is similar to the APL, possibly a relationship between these two variables, as observed in Table 2, the $\mathrm{N}$ contents were higher in the treatments with $40 \%$ of the organic sources, especially goat manure with $\left(0.40 \mathrm{~g} \mathrm{~kg}^{-1}\right)$ of $\mathrm{N}$. It is possible that goat manure has better availability of nutrients linked to vegetative growth, favoring greater development of rootstocks. According to Taiz \& Zeiger (2013) the $\mathrm{N}$ stimulates a greater synthesis of amino acids that promotes a greater accumulation of phytomass.

Similar behavior was also detected by
Oliveira et al. (2015), when evaluating guava seedlings, and under the same conditions, they observed that SDM had its values increased with the proportions of organic material and verified that the highest value obtained for SDM was $12.55 \mathrm{~g} \mathrm{plant}^{-1}$ in the proportion of $40,19 \%$.

Lap diameter data were adjusted to the quadratic regression model, with goat manure having the largest diameter $(5.67 \mathrm{~mm})$ in the proportion of $41.40 \%$, while bovine manure in the proportion of $43.07 \%$ resulted $(5.35 \mathrm{~mm})$, and the organic compound resulting $(3.93 \mathrm{~mm})$ in the maximum ratio of $60 \%$ (Figure 3 ). 


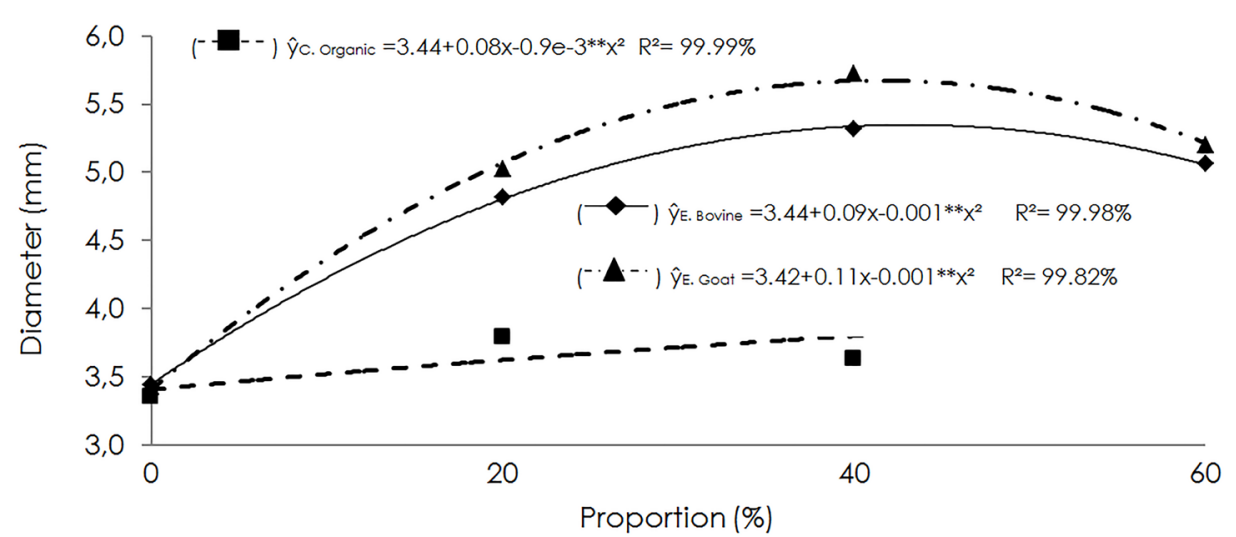

Figure 3. Collet diameter $(C D)$ of the tamarin rootstocks as a function of different proportions of organic matter incorporated into the substrates. Mossoró, RN, 2014.

The results were similar to those of Pereira that expressed the best results were those that et al. (2010), when evaluating types of substrates in the quality of tamarind seedlings, observed that the use of bovine manure provided the largest increases in stem diameter for plants when compared to the substrate with Plantmax®. This may be related not only to the nutrient content but also with the effect of the substrate on microbiological processes, aeration, structuring, water retention capacity and temperature regulation of the medium.

According to Table 2, it was observed that nutrient contents in the substrate with $40 \%$ of goat manure favored the balanced development between the aerial part and CD, an important fact, since the grafting of tamarind trees is recommended when the rootstocks reach $5 \mathrm{~cm}$ in the CD. used in the composition of the goat manure substrate, obtaining a maximum value of 63.87 leaves in the proportion of $43.37 \%$. Bovine manure in the proportion of $40.65 \%$ promoted a number of leaves of 51.85 , while the organic compound in the proportion of $46.21 \%$ resulted in 55.05 leaves. These results are similar to Mendonça et al. (2014) which studied different substrates in the production of tamarind rootstock and found that the best results were those that used soil and goat manure as substrate.

These results may be related to the rapid capacity to nutrient release, and to $\mathrm{pH}$ and $\mathrm{N}$ values of the substrate containing $40 \%$ goat manure (Table 2). Nitrogen is involved in all stages of plant development, so it probably influenced positively for this trait and the other According to Figure 4, the treatments organic compounds used showed high salinity.

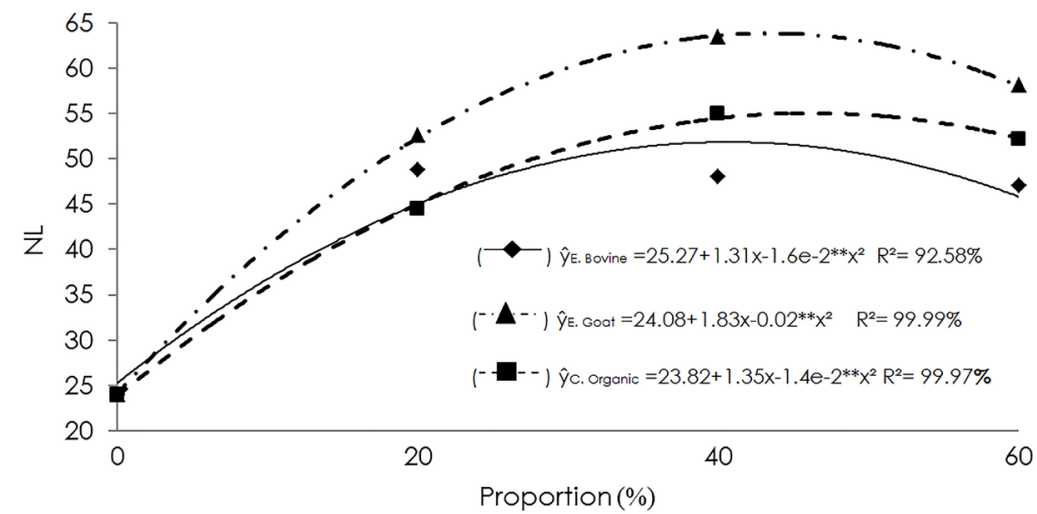

Figure 4. Number of leaves (NL) of the tamarind rootstocks as a function of different proportions of organic matter incorporated in the substrates. Mossoró, RN, 2014.

The organic sources provided a organic compound obtained the lowest values quadratic effect on the dry mass of the roots, and the goat manure was responsible for the maximum accumulation of $17.02 \mathrm{~g}$ at the rate of $36.99 \% \vee v^{-1}$, followed by bovine manure with with a maximum of $13.19 \mathrm{~g}$ in the proportion of $28.41 \% \vee v^{-1}$, according to (Figure 5). There was no significant effect of sources and proportions for the root length characteristic. $15.33 \mathrm{~g}$ in the proportion of $30.62 \% \vee v^{-1}$, while the 


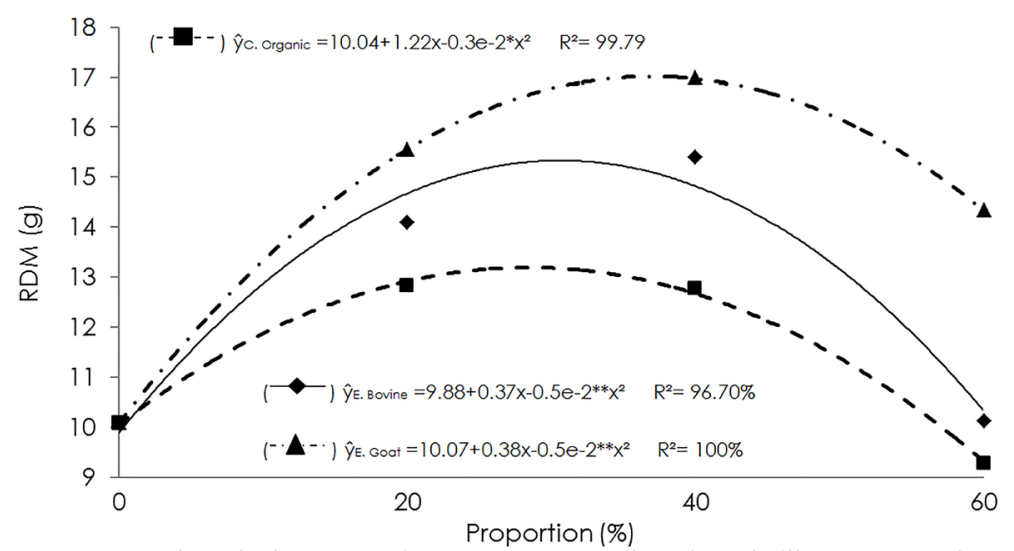

Figure 5. Root dry mass (RDM) of the tamarind rootstocks as a function of different proportions of organic matter incorporated into the substrates. Mossoró, RN, 2014.

Observing the RDM values, it can be inferred that one of the possible causes of these results may be related to the sodium levels in the substrate (Table 2), because in these treatments, regardless of the organic source used, in the proportion of $40 \%$ the levels of this nutrient were not higher as in other proportions, favoring root development, and possibly also contributing to higher RDM values. The tolerance limit of a plant species to salinity depends on the concentration of the salt present, the exposure time, as well as the stage of development of the plants. According to Cruz et al. (2006), the presence of sodium ( $\mathrm{Na}$ ) and chlorine ( $\mathrm{Cl}$ ) in the substrate causes reduction in the plant growth, as these ions cause, among other negative effects, changes in the plants' ability to absorb, transport and use other nutrients. The effects of these ions are related to the osmotic effect, which induces a condition of water stress to the plants and the direct toxic effect, mainly on the enzymatic and membrane systems.

A similar result was observed by Mendonça et al. (2014) evaluating tamarind seedlings and detected that the dry mass of the root system was better in the treatments in which soil substrate and goat manure were used, standing out from the other treatments.

The TDM values increased with the proportions of the organic materials and adapted to the quadratic regression model according to (Figure 6). The treatments in which goat manure was used in the substrate composition presented a TDM accumulation of $62.14 \mathrm{~g}$ in the proportion of $41.94 \%$, followed by bovine manure in the proportion of $37.24 \%$, promoting an TDM of 50.58 $\mathrm{g}$, while the organic compound in the proportion of $41.50 \%$ obtained a TDM of $48.89 \mathrm{~g}$.

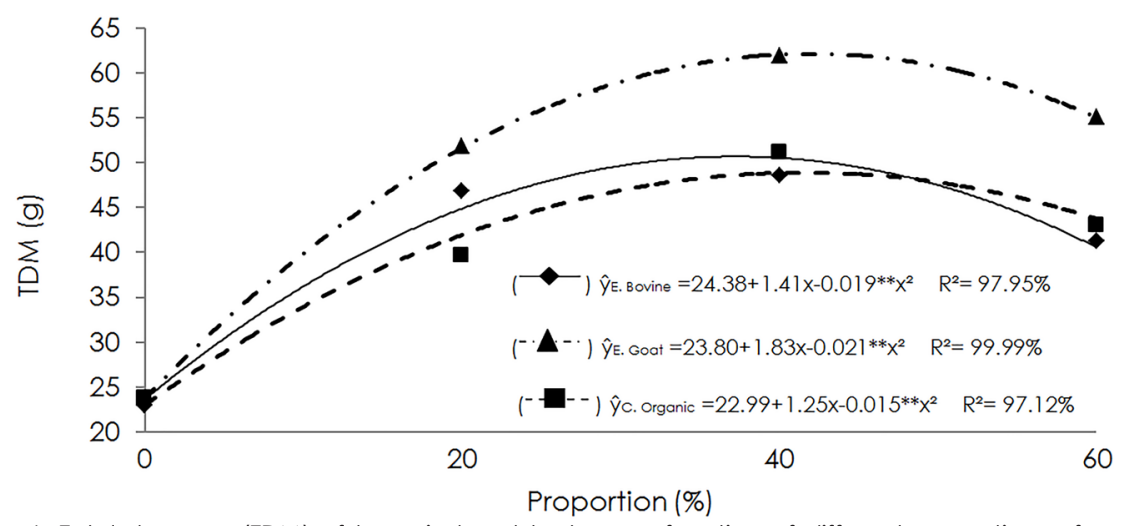

Figure 6. Total dry mass (TDM) of tamarind rootstocks as a function of different proportions of organic matter incorporated in the substrates. Mossoró, RN, 2014.

Probably, the promising results reached by goat manure in the accumulation of total dry mass are related to the lower salinity of this source of organic matter in relation to the other sources studied. This fact may have favored the greater accumulation of TDM. This tendency, observed in most of the variables analyzed, may follow as a possible explanation for the results found.

Mendonça et al. (2007), when studying the behavior of papaya seedlings in Mossoró 
submitted to different proportions of organic compound containing manure, observed that the best treatment was $40 \%$ for the total dry mass variable, a similar behavior was found in this study.

There was no significant interaction between the organic sources and proportions added to the substrate for the concentrations of nitrogen $(N)$, phosphorus $(P)$ and potassium $(K)$ in the dry mass of the aerial part.
The highest nitrogen content in the aerial part $\left(14.56 \mathrm{~g} \mathrm{~kg}^{-1}\right)$ occurred in the proportion of $35.46 \%$ for treatments with goat manure. Above this value, the proportions applied resulted in lower levels of nitrogen. The treatments that contained organic compounds in the maximum proportion of $60 \%$ obtained a nitrogen accumulation in the aerial part of (13.07 $\mathrm{g} \mathrm{kg}^{-1}$ ) (Figure 7). For bovine manure, no regression adjustment was obtained and only the means were used.

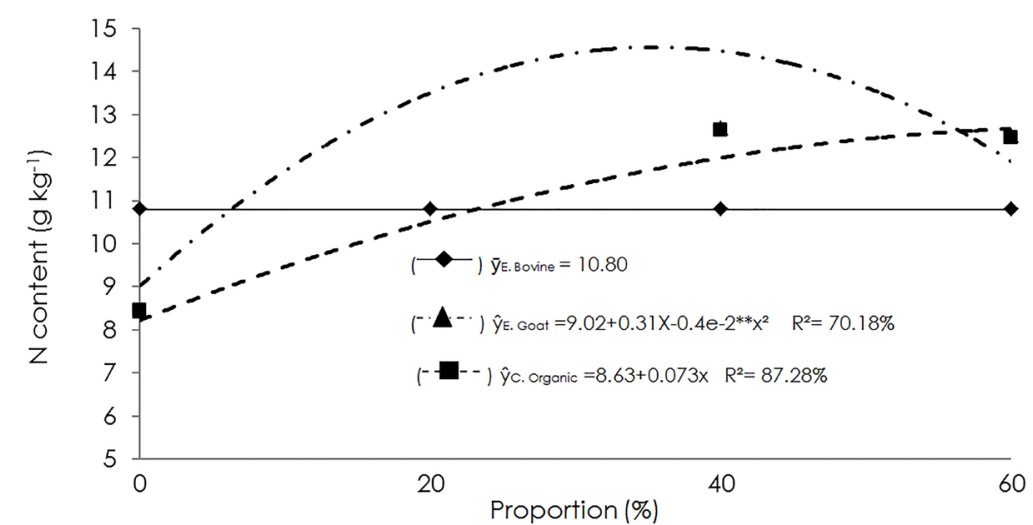

Figure 7. Nitrogen content $\left(\mathrm{g} \mathrm{kg}^{-1}\right)$ in the dry mass of the aerial part of the tamarind rootstocks, according to different proportions and organic sources incorporated to the substrate. Mossoró, RN, 2014.

Similar behavior was observed by Pereira (2010) studying the effect of chicken litter on the development of tamarind seedlings, in which the nitrogen content found in the aerial part of the seedlings was $12.15 \mathrm{~g} \mathrm{~kg}^{-1}$.

There was a decrease in the phosphorus content of the aerial part, with the increase of the proportions of the organic sources (goat manure and organic compound) according to (Figure 8). The bovine manure had different behavior, with an increase in the proportion there was an increase in the substrate, but in the aerial part its behavior occurred in an inverse way. This may have been due to the efficiency in the absorption and utilization of soil phosphorus by tamarind trees as a reflection of their adaptation to low fertility soils (Samarão, 2009; Dias et al., 2009) or as consequence of a possible dilution effect, once that occurred a higher production of dry mass with increased proportions of organic sources.

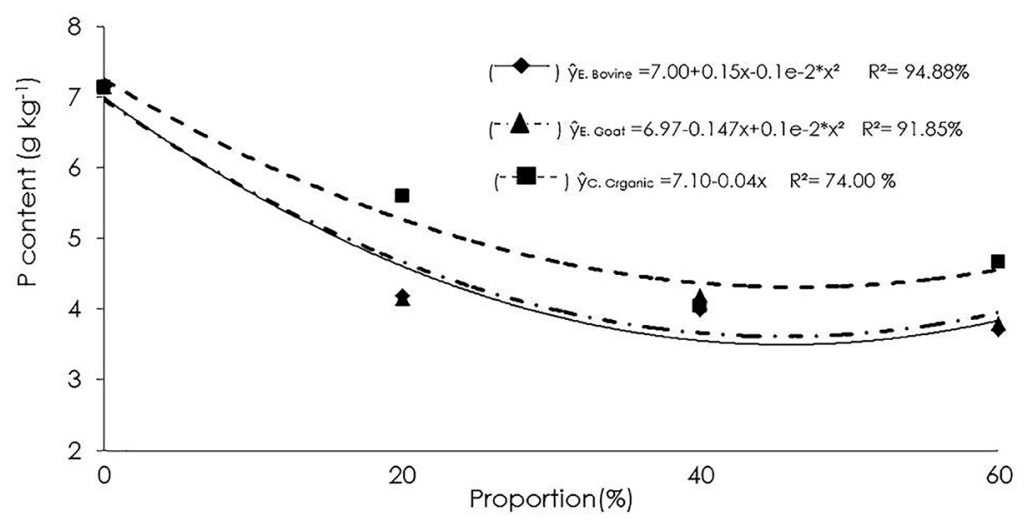

Figure 8. Phosphorus content $\left(\mathrm{g} \mathrm{kg}^{-1}\right)$ in the dry mass of the aerial part of the tamarind rootstock, as a function of different proportions of organic sources incorporated into the substrate. Mossoró, RN, 2014.

As for the potassium content $(K)$ in increased the potassium concentration in the the aerial part dry mass, it is observed that the tamarindseedlings, with the values being adjusted proportions of the organic sources in the substrate to the quadratic regression model (Figure 9). This 
is explained by Paula et al. (2010) in which they affirm that the manure favors the increase of the potassium content in the aerial part, because the organic matter in it contains this element almost in the totality of the exchangeable form, which contributes to its absorption by the root system. Another factor, may be the $\mathrm{pH}$ of the substrates (Table 1) in the range of 6.0 to 7.0 maximizes the absorption of $\mathrm{K}$.

\section{Conclusion}

The goat manure source provided the best results for the evaluated morphological characteristics.

The proportion of $40 \%$ of organic matter, independently of the organic source added to the substrate, favored the better development of the tamarind tree rootstocks.

\section{References}

Almeida, L.V.B., Marinho, C.S., Muniz, R.A., Carvalho, A.J.C. 2012. Disponibilidade de nutrientes e crescimento de portaenxertos de citros fertilizados com fertilizantes convencionais e de liberação lenta. Revista Brasileira de Fruticultura, 34: 289-296.

Cruz, J. L., Pelacani, C.R., Coelho, E.F., Caldas, R.C., Almeida, A.Q., Queiroz, J.R. 2006. Influência da salinidade sobre o crescimento, absorção e distribuição de sódio, cloro e macronutrientes em plântulas de maracujazeiro-amarelo. Bragantia, 65:275-284.

Dias, T.J., Pereira, W.E., Cavalcante, L.F., Raposo, R.W.C., Freire, J.L.O. 2009. Desenvolvimento e qualidade nutricional de mudas de mangabeiras cultivadas em substratos contendo fibra de coco e adubação fosfatada. Revista Brasileira de Fruticultura, 31: 512-523.

Dias, T.J., Pereira, W.E., Sousa, G.G. de. 2007. Fertilidade de substratos para mudas de mangabeira, contendo fibra de coco e adubados com fósforo. Revista Acta Scientiarum Agronomy, 29: 649-658.

EMBRAPA - Empresa Brasileira de Pesquisa Agropecuária. Manual de métodos de análises de solo, plantas e fertilizantes. Brasília, $2^{a}$ edição, 2009. 212p.

Ferreira, D.F. 2011 . Sisvar: A computer statistical analysis system. Ciência e Agrotecnologia 35: 1039-1042.

Ferreira, E.A., Mendonça, V., Souza, H.A. de, Ramos, J.D. 2008. Adubação fosfatada e potássica na formação de mudas de tamarindeiro. Scientia Agrária, 9: 475-480.

Góes, G.B., Dantas, D.J., Araújo, W.B.M., Melo, I.G.C., Mendonça, V. 2011 . Utilização de húmus de minhoca como substrato na produção de mudas de tamarindeiro. Revista Verde de Agroecologia e Desenvolvimento Sustentável, 6: 125-131.

Kusdra, J.F., Moreira, D.F., Silva, S.S., Araújo Neto, S.E., Silva, R.G. 2008. Uso de coprólitos de minhoca na produção de mudas de mamoeiro. Revista Brasileira de Fruticultura, 30: 492-497.

Jandel Scientific. Table curve: curve fitting software. Corte Madera, CA: Jandel Scientific, 1991. 280p.

Mendonça, V., Abreu, N.A.A., Souza, H.A., Ferreira, E.A., Ramos, J. D. 2007. Diferentes níveis de composto orgânico na formulação de substrato para a produção de mudas de mamoeiro 'formosa'. Revista Caatinga, 20: 49-53.

Mendonça, V; Melo, J.K.H.; Mendonça, L.F.M.; Leite, G.A.; Pereira, E.C. 2014. Avaliação de diferentes substratos na produção de portaenxertos de tamarindeiro. Revista Caatinga, 27: 60-66.

Mesquita, E.F. de., Chaves, L.H.G., Freitas, B.V., Silva, G.A., Sousa, M.V.R., Andrade, R. 2012. Produção de mudas de mamoeiro em função de substratos contendo esterco bovino e volumes de recipientes. Revista Brasileira de Ciências Agrárias 7: 58-65.

Morais, F.A. de., Góes, G.B. de., Costa, M.E. da., Melo, I.G.C., Veras, A.R.R., CUNHA, G.O. de M. 2012. Fontes e proporções de esterco na composição de substratos para produção de mudas de jaqueira. Revista Brasileira de Ciências Agrárias 7: 784-789.

Oliveira, F.T. de, Hafle, O.M., Mendonça, V., Moreira, J.N., Pereira Júnior, E.B., Rolim, H.O. 2015. Respostas de portaenxertos de goiabeira sob diferentes fontes e proporções de materiais orgânicos. Comunicata Scientiae, 6: 17- 25.

Paula, Y. C. M. Mendonça, V., Góes, G.B. de., Lima, A. S., Medeiros, L.F. de., Batista, T.M.V. 2010. Doses de sulfato de potássio na produção de portaenxerto de tamarindeiro (Tamarindus indica L.). Revista Brasileira de Ciências Agrárias, 2: $71-79$.

Pereira, E.C., Costa, J.M., Câmara, F.M.M., Farias, W.C., Mendonça, V. 2016. Growth and levels of $n, p$ and $k$ in rootstocks of tamarind trees using organic substrates and doses of phosphorus. Revista Caatinga, 29: 274-282.

Pereira, P.C., Melo, B., Freitas, R.S., Tomaz, M.A., Teixeira, I.R. 2010. Tamanho de recipientes e 
tipos de substrato na qualidade de mudas de tamarindeiro. Revista Verde de Agroecologia e Desenvolvimento Sustentável, 5:136-142.

Samarão, S.S., Martins, M.A. 2009. Influência de fungos micorrízicos arbusculares, associada à aplicação de rutina, no crescimento de mudas de goiabeira (Psidium guajava L.). Revista Brasileira de Fruticultura, 21: 196-199.

Silva, R.B.G., Simões, D., Silva, M.R. 2012. Qualidade de mudas clonais de Eucalyptus urophylla x Eucalyptus grandis em função do substrato. Revista Brasileira de Engenharia Agrícola e Ambiental, 16: 297-302.

Taiz, L., Zeiger, E. Fisiologia vegetal. 5.ed. Porto Alegre: Artmed, 201 